\title{
First evidences of Acartia bifilosa resting eggs in sediments of the Urdaibai estuary (Bay of Biscay): abundance and hatching success
}

\author{
IBON URIARTE ${ }^{1}$ and FERNANDO VILLATE ${ }^{2}$ \\ ${ }^{1}$ Laboratory of Ecology, Department of Plant Biology and Ecology, Faculty of Pharmacy, University of the Basque \\ Country, E-01006 Gasteiz. E-mail: ibon.uriarte@ehu.es \\ ${ }^{2}$ Laboratory of Ecology, Department of Plant Biology and Ecology, Faculty of Science and Technology, University of the \\ Basque Country, PO Box 644, 48008 Bilbao. E-mail: gvpvigul@lg.ehu.es
}

\begin{abstract}
SUMMARY: The abundance and hatching success of Acartia bifilosa resting eggs in subtidal sediments of the Urdaibai estuary was analysed in the context of a study on the spatial and temporal dynamics of this species. Two sediment cores of 20 to $30 \mathrm{~cm}$ depth were obtained at two sites of the middle zone, where the accumulation of mud and organic particles is favoured. Laboratory incubations were performed to determine the hatching success of eggs and identify newborns. Resting egg abundance was around $10^{7}$ eggs $\mathrm{m}^{-2}$, and was higher at the site where the A. bifilosa population maintains an optimal position in the water column. The lower egg abundance in upper layers, as corresponds to winter, was associated with the seasonal dynamics of planktonic populations. On average, the hatching success was $>50 \%$ at both sites. The lack of significant differences in the hatching success according to sediment depth suggests that eggs remain viable after being buried for a long-time in anoxic conditions. This enables us to infer that the benthic egg bank of A. bifilosa in this estuary is a safe source of recruits into the planktonic population, and plays a crucial role in recuperation and maintenance of the population.
\end{abstract}

Keywords: Acartia bifilosa, resting eggs, Urdaibai estuary .

RESUMEN: PRIMERAS EVIDENCIAS DE HUEVOS DE RESISTENCIA DE ACARTIA BIFILOSA EN SEDIMENTOS DEL ESTUARIO DE URDAIBAI (GOLFO DE BIZKAIA): ABUNDANCIA Y ÉXITO DE ECLOSIÓN. - Se analizó la abundancia y éxito de eclosión de los huevos de resistencia de Acartia bifilosa en sedimentos submareales del estuario de Urdaibai, en un contexto sobre el estudio de la dinámica espacio-temporal de esta especie. Se obtuvieron dos cores de $20-30 \mathrm{~cm}$ de profundidad en dos puntos de la zona media del estuario, donde la acumulación de partículas se ve favorecida. Se realizaron incubaciones en laboratorio para determinar el éxito de eclosión de los huevos y la identificación de los recién nacidos. La abundancia de los huevos de resistencia fue alrededor de $10^{7}$ huevos $\mathrm{m}^{-2}$, siendo mayor en el punto donde la población de A. bifilosa mantiene su posición óptima en la columna de agua. La menor abundanciade huevos de las capas superiores se asoció a la dinámica estacional de la población planctónica. De media, el éxito de eclosión fue $>50 \%$ en ambos puntos. La ausencia de diferencias significativas en el éxito de eclosión respecto a la profundidad del sedimento sugiere que los huevos permanecen viables incluso tras una larga acumulación en condiciones anóxicas. Esto nos permite inferir que el banco de huevos bentónicos de A. bifilosa en este estuario es una fuente segura de reclutas a la población planctónica y que juega un papel crucial en la recuperación y mantenimiento de la población.

Palabras clave: Acartia bifilosa, huevos de resistencia, estuario de Urdaibai.

\section{INTRODUCTION}

Resting stages afford species a temporal "refugium" from adverse conditions (Marcus and Boero, 1998). Therefore, in a great variety of short- lived aquatic organisms (e.g. Viitasalo and Katajisto, 1994; Belmonte et al., 1997; Hairston et al., 2000), resting eggs are considered as critical for the perpetuation of populations from year to year, particularly in the case of those that disappear from 
the water column for a part of the year (Uye, 1985; Marcus, 1989) or those that undergo strong seasonal fluctuations (Katajisto et al., 1998). In planktonic organisms, hatching from resting eggs enables a multiple acceleration of population increase during the beginning of the development of a population with periodical re-establishment from this phase (Boero, 1994; Arbaciauskas and Gasiunaité, 1996), and is of great importance in explaining species fluctuations in space and time (Giangrande et al., 1994) and benthic-pelagic coupling (Boero et al., 1996; Marcus and Boero, 1998). Moreover, these resting eggs can remain viable for long time, which exceeds the individual life span of species by a noticeable amount. Marcus et al. (1994) found calanoid copepod viable eggs $>40$ years old in the deepest layers of the seabed and Hairston et al. (1995) estimated a longevity of $>300$ years for the hatched eggs of freshwater species obtained from lake sediments. Therefore, zooplankton egg banks in sediments can serve as repositories of both genetic and ecological information (Limburg and Weider, 2002) and are natural archives that can provide environmental information (Wik and Renberg, 1991).

Production of resting eggs is well documented for several species of the family Acartiidae (e.g. Uye, 1980; Belmonte and Puce, 1994; Marcus, 1995; Norrbin, 1996; Belmonte, 1997; Guerrero and Rodríguez, 1998), including Acartia bifilosa (e.g. Viitasalo, 1992b; Katajisto, 1996, Katajisto et al., 1998; Castro-Longoria and Williams, 1999; Chinnery and Williams, 2003). This species shows a great adaptability to environments with different salinity, from the mesohaline waters of the Baltic Sea (Viitasalo, 1992a) to the polyhaline and mesohaline regions of large estuaries, such as the Severn (Collins and Williams, 1981), the Gironde (Castel, 1981), the Forth (Taylor, 1987) and the Ems (Baretta and Malschaert, 1988), and some shallow lagoons (Lam-Hoai, 1985). In the case of the Urdaibai estuary three Acartiidae species have been found inhabiting it; A. bifilosa, A. clausi and Paracartia grani (Villate et al., 1993), although the last one was found only once (five individuals in samples from September 1998) during a sampling programme of the zooplankton community (Uriarte and Villate, 2005).

In the small estuaries of the Basque coast (Bay of Biscay) A. bifilosa is the main autochthonous brackish-water copepod (Villate and Orive, 1981; San Vicente et al., 1988; Villate, 1991b) and dominates the copepod community of the polyhaline region ( $<30$ salinity), but its population maximum in summer usually moves to euhaline waters because of the increasing salinity upward the estuary during the dry season (Villate, 1997; Villate et al., 1993). Although perennial, its populations are found to fluctuate drastically in relation to hydrological instability inherent to these systems, and may occasionally be absent in zooplankton samples during river flood events (Uriarte et al., 1998), suggesting that they can disappear or remain in negligible densities in the water column under such conditions. On the other hand, A. clausi is the main neritic species of the Bay of Biscay (d'Elbée and Castel, 1991; Villate et al., 1997; Valdés and Moral, 1998). It penetrates into the estuaries, where in spring it shows its population maximum.

This work is a preliminary analysis of the resting egg banks of A. bifilosa in the Urdaibai estuary. Our main aim was to report the first evidences of resting eggs of A. bifilosa accumulated in the subtidal soft sediments of the Urdaibai estuary and to evaluate their abundance and hatching success in order to complete, and in part improve, previous information on unidentified Acartia resting eggs from intertidal sediments of this estuary (Masero and Villate, 2004). Another aim was to relate this to the distribution of A. bifilosa in the pelagic habitat and to natural or anthropic perturbing factors that can affect benthic egg banks in estuaries.

The Urdaibai estuary $\left(43^{\circ} 22^{\prime} \mathrm{N}, 2^{\circ} 43^{\prime} \mathrm{W}\right)$, also called the Mundaka estuary, is a $\sim 13 \mathrm{~km}$ long, shallow (2.5 m mean depth), mesotidal and mainly mixed system (Fig. 1). The pelagic subsystem is characterised by the predominance of euhaline waters which usually penetrate beyond the middle of the estuary at high tide, and polyhaline waters that usually move from the upper estuary at high tide to the middle estuary at low tide (Villate, 1997). Consequently, the zooplankton of the outer part is mainly composed of neritic species that can penetrate as far as the inner estuary by tidal transport, while the main autochthonous estuarine copepod, $A$. bifilosa, shows the highest development in the middle-inner zone (Villate, 1991b; Villate et al., 1993). This estuary has extensive intertidal flats in the outer part and marshes in the middle and inner parts. Intertidal sediments are constituted by clean sands in the low estuary, but mud presence and habitat heterogeneity increase towards the middle estuary (Borja, 1988). The bed of the main channel remains 
sandy as far as the middle estuary where the higher mud percentages $(>40 \%)$ in subtidal sediments have been recorded (Cotano, 2003).

\section{MATERIAL AND METHODS}

A broad sampling programme for the study of the zooplankton community in the Urdaibai estuary was undertaken between February 1998 and December 1999. Except in March and June 1999, zooplankton samples were obtained monthly by oblique tows with a $200 \mu \mathrm{m}$ mesh net (mouth diameter: $50 \mathrm{~cm}$ ) provided with a no-filtering cod-end to prevent damage to the copepods and equipped with a General Oceanics flowmeter. Individuals were caught at fixed salinity sites of around 35, 33, 30 and 26, the last two corresponding to the optimal salinity range for A. bifilosa in Urdaibai (Villate et al., 1993). After retrieval, the catches were preserved in $4 \%$ buffered (pH range: 6.9-7.1) formalin for subsequent examination in the laboratory. Only A. bifilosa specimens caught at 26 were taken into account for this study.

In the survey carried out in February 1999, two subtidal sediment samples were also taken from the bed of the main channel at two sites of the inner and middle regions of the estuary (Fig. 1). Site A was near the end of the artificial channel that meets the upper reaches and the middle estuary, whilst site B was located at the outer end of the middle zone, in a curve near the outer limit for the presence of fine inorganic particles and high organic contents in subtidal sediments (Cotano, 2003). Sediment samples were obtained by mean of a $\mathrm{KB}^{\mathrm{TM}} 2$ " core sampler $(4.7 \mathrm{~cm}$ in diameter and $50 \mathrm{~cm}$ in length) provided with a nosepiece and an eggshell catcher to avoid disturbing the sediment layers. Cores were stored at $4^{\circ} \mathrm{C}$ in total darkness until their processing within 2 months. Ambient bottom water was collected and filtered (Whatmann GF/C) to be used for processing samples and for subsequent incubations of the extracted resting eggs.

Both sediment cores were divided at $1.0 \mathrm{~cm}$ intervals down to a depth of $25 \mathrm{~cm}$ (site A) and 29 $\mathrm{cm}$ (site B). These slices were divided into two halves; one for counting eggs and the other for hatching success analysis. Eggs were removed from sediment by the sugar flotation method introduced by Onbé (1978) and modified by Marcus (1990). The eggs for counting were preserved in $2 \%$ buffered formalin and analysed using an invert-

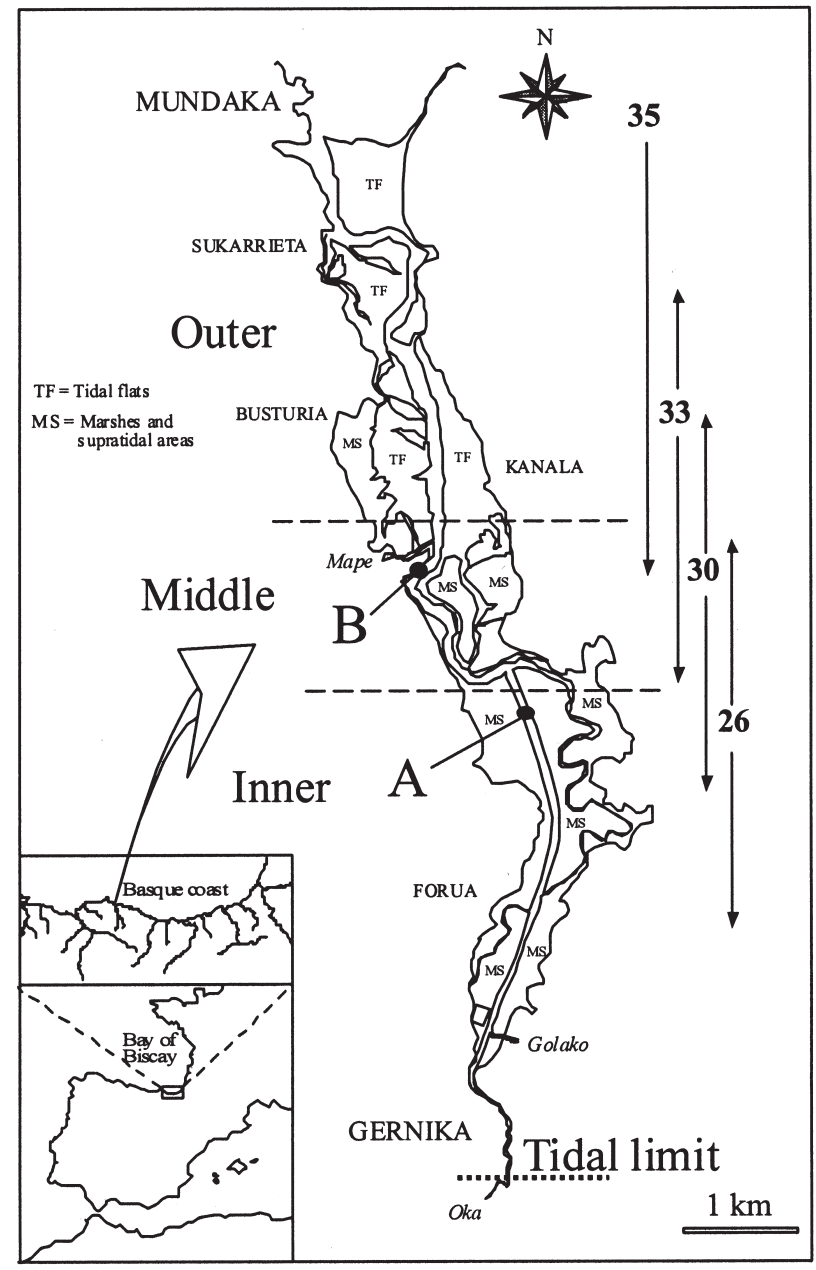

FIG. 1. - Sediment sample sites (A and B) and extentions of salinities where plankton samples were collected in the Urdaibai estuary.

ed Olympus microscope at a magnification of 400x. Eggs were identified according to the egg descriptions from the literature (Viitasalo and Katajisto, 1994; Castro-Longoria and Williams, 1999; Castro-Longoria, 2001) and to comparisons with the subitaneous eggs of A. bifilosa obtained in egg production experiments in the same estuary (Uriarte et al., 1998).

Eggs for hatching were extracted in a similar way to eggs for counting, since neither sonication (Marcus, 1984a) nor centrifugation (Onbé, 1978) should affect the eggs' viability. After centrifugation and washing, the eggs of each slice were placed with a Pasteur pipette onto $1 \mathrm{ml} 24$-well microtitration plates (range: 6-39 eggs per well) with GF/C filtered and autoclaved estuarine water. Plates were incubated at $18-20^{\circ} \mathrm{C}$ under a natural light regime. Incubation lasted for $\sim 20 \mathrm{~d}$ to allow rearing to an identifiable stage, and hatched nauplii and 


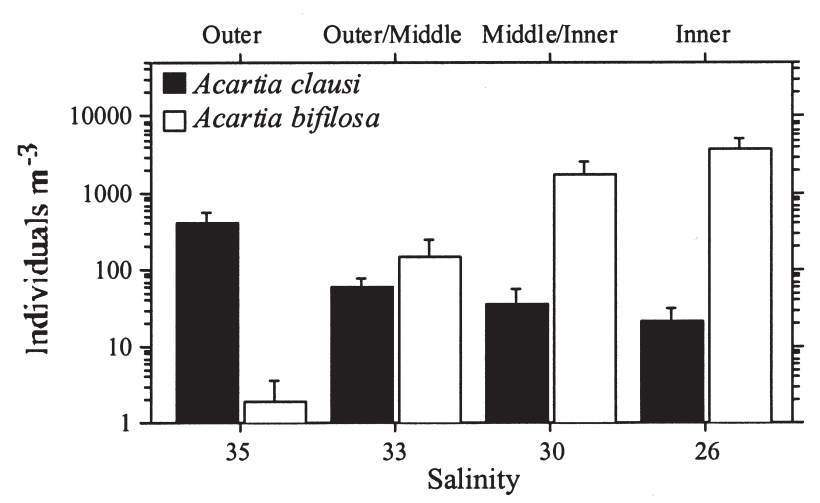

FIG. 2. - Densities of Acartia clausi and A. bifilosa along salinity/ spatial gradient in the Urdaibai estuary .

unhatched eggs were checked every 2 d. Every day, water was carefully renewed and laboratory-cultured Isochrysis galbana was used as food supply (in exponential growth phase: $2-2.510^{5}$ cells $\mathrm{ml}^{-1}$ ).

The components of mesozooplankton samples were identified and counted under a stereoscopic microscope by examining the required aliquots extracted from the total sample after a gentle homogenisation process.

Vertical differences in egg abundance and hatching success were tested by the non-parametric Kruskall-Wallis test (untransformed data). To compare and show vertical differences in egg abundance and hatching success, we considered the values obtained from the sum of $3 \mathrm{~cm}$ intervals.

\section{RESULTS}

\section{Spatial distribution of Acartia species}

In the Urdaibai estuary, the autochthonous estuarine species A. bifilosa showed a spatial distribution pattern inverse to that of the congeneric neritic species A. clausi, A. bifilosa being clearly dominant in $<33$ salinity waters and $A$. clausi in $>33$ salinity waters (Fig. 2).

\section{Acartia bifilosa population dynamic}

A. bifilosa showed a clear seasonal pattern, with higher abundances in summer (peaks of 16646 ind. $\mathrm{m}^{-3}$ in September 1998 and of 21596 ind. $\mathrm{m}^{-3}$ in July 1999 at the 26 salinity site) and lower abundances in the autumn-winter period (a minimum of 19 ind. $\mathrm{m}^{-3}$ in February 1999 and of 15 ind. $\mathrm{m}^{-3}$ in November 1999) (Fig. 3). A clear decrease was recorded in

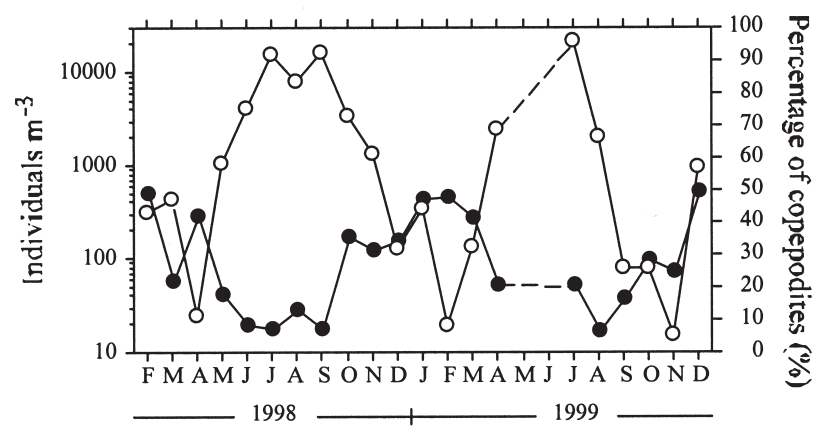

FIG. 3. - Temporal variations in Acartia bifilosa densities (blank circles) and in percentage of $A$. bifilosa copepodites (filled circles) at salinity 26 in the Urdaibai estuary from February 1998 to December 1999.

April 1998 (24 ind. $\mathrm{m}^{-3}$ ), but the population recovered during the subsequent months. The percentage of copepodites was always $<50 \%$, because of the loss of early stages in the $>200 \mu \mathrm{m}$ fraction, but their relative abundance showed a significant negative correlation (Pearson correlation, $\mathrm{p}=0.0152$ ) with population abundance.

\section{Benthic egg abundance and hatching success}

The majority of eggs extracted from sediments were resting eggs of calanoid copepods and rotifers. Calanoid egg abundance ranged between $0.8 \cdot 10^{7}$ and $11.0 \cdot 10^{7}$ eggs $\mathrm{m}^{-2}$ in sediments collected at site A, and between $0.5 \cdot 10^{7}$ and $4.0 \cdot 10^{7}$ eggs $^{-2}$ at site B. Vertically, calanoid eggs showed a maximum at around 4-6 cm depth at both sites, and were distributed more homogenously with depth at site B (Fig. 4a). Variations with sediment depth were only significant at site A (Table 1).

Hatching success ranged between 56.3 and $87.2 \%$ for benthic eggs from site A and between 36.5 and $82.3 \%$ for benthic eggs from site $\mathrm{B}$, being $>50 \%$ on average for both, and no clear trends in egg hatching with depth were observed (Fig. 4b). No significant differences in egg hatching with depth were found at any site (Table 1).

The majority of eggs hatched in the first $4 \mathrm{~d}$ of incubation. However, most individuals died at early naupliar stages and only five individuals became adults, all them of the species A. bifilosa. Taking this into account, in addition to the comparisons of eggs extracted from the sediment and hatched nauplii with the subitaneous eggs and nauplii of $A$. bifilosa obtained in egg production experiments in the same estuary (Uriarte et al., 1998), and the dominance of this species in the sites where sediment 

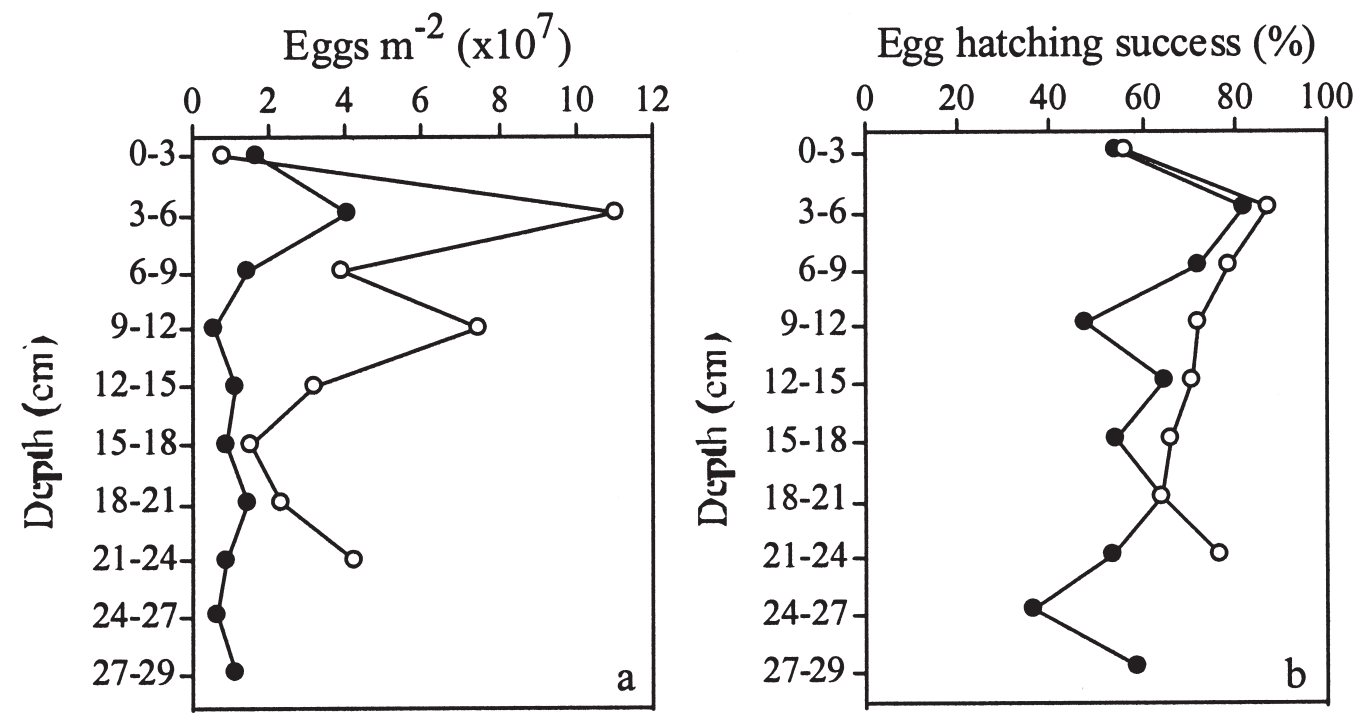

FIG. 4. - Vertical variations in Acartia bifilosa resting eggs abundance (a) and hatching success (b) in the sediments of site A (blank circles) and site B (filled circles) of the Urdaibai estuary. Sum of three cm-deep layers is represented.

TABLE 1. - Mean and standard deviation (S.D.) and vertical differences (Kruskall-Wallis test) of the egg abundance (eggs $\mathrm{m}^{-2}$ ) and hatching success $(\%)$ in the subtidal sediments of site A and B of the Urdaibai estuary. Significant results $(\mathrm{p}<0.05)$ in bold.

\begin{tabular}{|c|c|c|c|c|c|c|}
\hline & \multirow{2}{*}{\multicolumn{2}{|c|}{ Site A }} & \multirow{2}{*}{\multicolumn{2}{|c|}{ Site B }} & \multicolumn{2}{|c|}{ Vertical differences } \\
\hline & & & & & Site A & Site B \\
\hline & Mean & S.D. & Mean & S.D. & $p$ & $p$ \\
\hline Eggs $\mathrm{m}^{-2}$ & $1.4 \cdot 10^{7}$ & $1.3 \cdot 10^{7}$ & $4.7 \cdot 10^{6}$ & $6.1 \cdot 10^{6}$ & 0.0148 & 0.5615 \\
\hline Egg hatching success (\%) & 71.7 & 15.0 & 58.9 & 18.8 & 0.2913 & 0.2250 \\
\hline
\end{tabular}

samples were obtained (Fig. 2), we assumed that all eggs belonged to A. bifilosa, because the error attributable to unidentified eggs can be considered negligible.

\section{DISCUSSION}

The existence and dominance of Acartia eggs in the egg bank of the intertidal sediments of the Urdaibai estuary was reported in a previous study (Masero and Villate, 2004) resulting from a visual identification of eggs based on morphological descriptions from literature. Now we have verified by incubation experiments that the copepod egg bank of the sediments of this estuary are mainly made up of $A$. bifilosa resting eggs. The neritic species $A$. clausi is co-dominant together with $A$. bifilosa in this estuary but both species are clearly segregated (Villate et al., 1993), A. clausi occurring mainly in lower reaches where sandy sediments and tidal export predominate. Therefore, the fate of its eggs would mainly be located out the estuary, whereas the sink and retention of A. bifilosa eggs within the estuary is warranted due to the upward location of this species. Maximum egg abundance found in subtidal sediments of Urdaibai are comparable to those reported for A. bifilosa on the bottom of the Baltic Sea (Viitasalo, 1992b), and we can assume that losses by export out the estuary are low. By comparison with the above-mentioned study in intertidal sediments of the Urdaibai estuary, we also found that the abundance of eggs was around two orders of magnitude higher in subtidal sediment than in intertidal sediments, in accordance with the differential sedimentation rate of particles that can be expected in the two sedimentary habitats, but a similar trend of spatial distribution along the estuary was observed.

Vertical distribution of eggs evidenced the presence of higher accumulations in sub-upper layers than in upper ones. This is also reported in other studies (De Stasio, 1989; Ban, 1992; Næss, 1991), including that carried out in the intertidal sediment of the Urdaibai estuary (Masero and Villate, 2004). It has been interpreted in different ways, but gener- 
ally involving short-term processes. Plausible causes for the occurrence of peaks in buried eggs are rapid burial that inhibit hatching (Katajisto, 1996; Madhupratap et al., 1996), high egg production under unfavourable conditions for the population development (Gilbert and Schreiber, 1995) or unfavourable conditions in bottom water that inhibited egg hatching (Madhupratap et al., 1996). The density of eggs on the surface also seems timedependent in a seasonal context, depending on egg production rates and egg hatching rates linked to planktonic population dynamics. Co-occurring decreases of the planktonic population and the number of eggs in sediments has been reported for Paracartia grani during the adverse winter period (Guerrero and Rodriguez, 1998). According to this, the low egg abundance recorded in upper layers in February would correspond to the expected decrease of resting eggs in winter, since minimal densities for A. bifilosa in the plankton occur in this season. The coincidence of higher proportions of developmental stages (copepodids) in the population in winter could be interpreted in terms of a higher contribution of benthic egg hatching to the population recruitment. This is also supported by the fact that egg production rates for A. bifilosa in the Urdaibai estuary peak in spring, and the absolute egg production maxima occur in summer, coinciding with the annual population maxima (Uriarte et al., 1998). Therefore, the sudden recoveries of the population from winter to spring, such as those observed in this study in April-May 1998 and February-April 1999, could not be only explained by egg production from remaining individuals in plankton. Linking between benthic resting eggs and abundance of copepods is well documented in Acartia (Kasahara et al., 1975; Uye, 1983; Guerrero and Rodríguez, 1998), and Viitasalo (1992b) concluded that the annual population dynamic of A. bifilosa in the Baltic Sea consisted of a first generation hatched from the sediment and a variable number of subsequent generations.

The vertical distribution of eggs in the sediment is also dependent on factors that affect egg burial and vertical movement (Katajisto, 1996). Among natural physical factors, storms and deep-currents may have an effect by inducing resuspension and sediment mixing, mainly in shallow systems, but bioturbation by benthic organisms may also be important (Marcus, 1984a; Marcus and SchmidtGengenbach, 1986), as well as physical perturbation by human activities (Masero and Villate, 2004). In our case, the rather homogenous distribution of eggs at site B could be mainly related to this last fact, because of the dredging activities for launching ships that are carried out from the shipyard located in front of site B, while the effects of natural factors that may induce sediment mixing seem similar at sites A and B. Both are located in the middle zone, in a narrow channel surrounded by supratidal marsh areas and sheltered from wind-induced turbulence, and the speed of bottom tidal currents is similar (Villate, 1997).

Hatching success values for resting eggs recorded in the Urdaibai estuary fall into the range of values found in other systems (Marcus and Lutz, 1998), and seem to reflect the healthy condition of this estuary, since Lindley et al. (1998) found a consistent reduction in egg viability with increasing pollution. In this study, the reported rates of hatching success in calanoid benthic eggs were 92,48 and $14 \%$ respectively in three estuaries with increased pollution.

The lower egg hatching success found in upper layers might be related to the existence of diapause eggs that do not hatch until they have completed a refractory phase lasting from weeks to months (Grice and Marcus, 1981), whilst in older eggs of sub-upper layers the refractory phase should be finished. However, we recorded smooth-surface eggs considered subitaneous but not the morphologically distinct spiny form described by Castro-Longoria and Williams (1999) as the diapause egg type for $A$. bifilosa. Katajisto (2003) deduces that A. bifilosa does not produce diapause eggs in the Baltic Sea, and suggests that this species presents different strategies consisting in producing diapause eggs only in areas where the planktonic population is totally absent at any time of the year. According to this, the selection pressure for the production of diapause forms in A. bifilosa will be lacking in the Urdaibai estuary, where a perennial species is found.

As egg hatching success was high at sub-upper layers and did not show significant differences with depth, we deduce that benthic eggs in the sediment of the estuary remain viable in anoxic conditions for a long time. In the upper layers of intertidal sediments of the middle reaches, Eh values ranging from -150 to $-300 \mathrm{mV}$ have been measured (unpublished data), thereby denoting the reduced condition of these sediments. Benthic resting eggs do not hatch in the absence of oxygen (Ban and Minoa, 1992; Marcus and Lutz, 1994), but remain viable and can contribute to the recruitment of planktonic popula- 
tion when they access the appropriate environmental conditions to hatch by natural bioturbation or human physical perturbation of sediments. The lower egg hatching success at site $\mathrm{B}$ might be related to the higher hatching rate of eggs due to the effect of the above-mentioned dredging activities in that zone. Periodical mixing and resuspension may enhance the hatching chance for viable buried eggs, thus increasing the proportion of non-viable eggs in the remaining benthic bank.

In summary, the high number and hatching success values of resting eggs collected from the sediments reveal the crucial role of benthic egg banks for A. bifilosa in the Urdaibai estuary, since this species undergoes strong seasonal fluctuations in this system. Furthermore, the huge reserve of potential viable eggs even at deep layers constitutes an "archive" that may offer important ecological information. Although the present work is a first attempt, and more investigation is needed, our results indicate that sediments located at unperturbed sites of the estuary can provide valuable information about the recent history of $A$. bifilosa and the environmental changes in the past.

\section{ACKNOWLEDGEMENTS}

Financial support for this research was provided by the University of the Basque Country UPV118.310-EA207/98 and by a grant to I. Uriarte from the Department of Education, Universities and Research of the Basque Government. Thanks to the team of the ecology laboratory, and especially to U. Cotano for help in carrying out this research.

\section{REFERENCES}

Arbaciauskas, K. and Z.R. Gasiunaté. - 1996. Growth and fecundity of Daphnia after diapause and their impact on the development of a population. Hydrobiologia, 320: 209-222.

Ban, S. and T. Minoda. - 1992. Hatching of diapause eggs of Eurytemora affinis (Copepoda: Calanoida) collected from lakebottom sediments. J. Crust. Biol., 12: 51-56.

Ban, S. - 1992. Seasonal distribution, abundance and viability of diapause eggs of Eurytemora affinis (Copepoda: Calanoida) in the sediment of lake Ohnuma, Hokkaido. Bull. Plankton Soc. Japan, 39: 41-48.

Baretta, J.W. and J.F.P. Malschaert. - 1988. Distribution and abundance of the zooplankton of the Ems estuary (Nortn Sea). Neth. J. Sea Res., 22: 69-81.

Belmonte, G. and M. Puce. - 1994. Morphological aspects of subitaneous and resting egs from Acartia josephinae (Calanoida). Hidrobiología, 292/293: 131-135.

Belmonte, G. - 1997. Resting eggs in the life cycle of Acartia italica and A. adriatica (Copepoda, Calanoida Acartiidae).
Crustaceana, 70: 114-117.

Belmonte, G., A. Miglietta, F. Rubino and F. Boero. - 1997. Morphological convergence of resting stages of planktonic organisms: a review. Hydrobiologia, 355: 159-165.

Boero, F. - 1994. Fluctuations and variations in coastal marine environments. Mar. Ecol. P.S.Z.N. I, 15: 3-25.

Boero, F., G. Belmonte, G. Giovanni, S. Piraino and F. Rubino. 1996. The continuity of living matter and the discontinuities of its constituents: do plankton and benthos really exist? TREE, 11: $177-180$.

Borja, A. - 1988. Estudio de las comunidades de moluscos de las rías de Euskadi. Informes Técnicos n ${ }^{\circ} 2445$ pp. Eusko Jaurlaritza, Gasteiz.

Castel, J. - 1981. Aspects de l'étude écologique du zooplankton de l'estuaire de la Gironde. Oceanis, 6: 535-577.

Castro-Longoria, E. - 2001. Comparative observations on the external morphology of subitaneous and diapause eggs of Acartia species from Southampton water. Crustaceana, 74: 225-236.

Castro-Longoria, E. and J. Williams. - 1999. The production of subitaneous and diapause eggs: a reproductive strategy for Acartia bifilosa (Copepods: Calanoida) in Southampton Water, UK. J. Plankton Res., 21: 65-84.

Collins, N.R. and R. Williams. - 1981. Zooplankton of the Bristol Channel and Severn Estuary: the distribution of four copepods in relation to salinity. Mar. Biol., 64: 273-283.

Cotano, U. - 2003. Variabilidad espacio-temporal de la concentración y composición bioquímica del seston y del material sedimentado en dos estuarios con diferente grado de alteración antrópica: Bilbao y Mundaka. Ph. D. thesis, UPV/EHU.

Chinnery, F.E. and J.A. Williams. - 2003. Photoperiod and temperature regulation of diapause egg production in Acartia bifilosa from Southamptom Water. Mar. Ecol. Prog. Ser., 263: 149-157.

d'Elbée, J. and J. Castel. - 1991. Zooplankton from the continental shelf of the southern Bay of Biscay exchange with Arcachon Basin, France. Ann. Inst. Oceanogr., 67: 35-48.

De Stasio, B.T. Jr. - 1989. The seed bank of a freshwater crustacean: copepodology for the plant ecologist. Ecology, 70: $1377-1389$.

Giangrande, A., S. Geraci and G. Belmonte. - 1994. Life-cycle and life-history diversity in marine invertebrates and the implications in community dynamics. Oceanogr. Mar. Biol. Ann. Rev., 32: 305-333.

Gilbert, J.J. and D.K. Schreiber. - 1995. Induction of diapausing amictic eggs in Synchaeta pectinata. Hydrobiologia, 313/314: 345-350.

Grice, G.D. and N.H. Marcus. - 1981. Dormant eggs of marine copepods. Oceanogr. Mar. Biol. Ann. Rev., 19: 125-140.

Guerrero, F. and V. Rodríguez. - 1998 Existence and significance of Acartia grani resting eggs (Copepoda: Calanoida) in sediments of a coastal station in the Alboran Sea (SE Spain). $J$. Plankton Res., 20: 305-314.

Hairston, N.G. Jr., R. Van Brunt Jr. and C.M. Kearns. - 1995. Age and survivorship of diapausing eggs in a sediment egg bank. Ecology, 76: 1706-1711.

Hairston, N.G. Jr., A.-M. Hansen, W.R. Schaffner. - 2000. The effect of diapause emergence on the seasonal dynamics of a zooplankton assemblage. Freshw. Biol., 45: 133-145.

Kasahara, S., S.-I. Uye and T. Onbé. - 1975. Calanoid copepod eggs in sea-bottom muds. II. Seasonal cycles of abundance in the populations of several species of copepods and their eggs in the Inland Sea of Japan. Mar. Biol., 31: 25-29.

Katajisto, T. - 2003. Development of Acartia bifilosa (Copepoda: Calanoida) eggs in the northern Baltic Sea with special reference to dormancy. J. Plankton Res., 25: 357-364.

Katajisto, T. - 1996. Copepod eggs survive a decade in the sediments of the Baltic Sea. Hydrobiologia, 320: 153-159.

Katajisto, T., M. Viitasalo and M. Koski. - 1998. Seasonal ocurrence and hatching of calanoid eggs in sediments of the northern Baltic Sea. Mar. Ecol. Prog. Ser., 162: 133-143.

Lam-Hoai, T. - 1985. Évolution saisonnière du zooplancton dans trois sites peu profonds de Thau, une lagune nord-méditerranéenne. Hydrobiologia, 128: 161-174.

Limburg, P.A. and L.J. Weider. - 2002. "Ancient" DNA in the resting egg bank of a microcrustacean can serve as a palaeolimnological database. Proc. R. Soc. Lond., B, 269: 281-287.

Lindley, J.A., C.L. George, S.V. Evans and P. Donkin. - 1998. Viability of calanoid copepod eggs from intertidal sediments: a 
comparison of three estuaries. Mar. Ecol. Prog. Ser. 162: 183-190.

Madhupratap, M., S. Nehring and J. Lenz. - 1996. Resting eggs of zooplankton (Copepoda and Cladocera) from the Kiel Bay and adjacent waters (southwestern Baltic). Mar. Biol., 125: 77-87.

Marcus, N.H. and F. Boero. - 1998. Minireview: the importance of benthic-pelagiccoupling and the forgotten role of life cycles in coastal aquatic systems. Limnol. Oceanogr., 43: 763-768.

Marcus, N.H. and J. Schmidt-Gengenbach. - 1986. Recruitment of individuals into the plankton: the importance of bioturbation. Limnol. Oceanogr., 31: 206-210.

Marcus, N.H. and R.V. Lutz. - 1994. Effects of anoxia on the viability of subitaneous eggs of planktonic copepods. Mar. Biol., 121: 83-87.

Marcus, N.H. and R.V. Lutz. - 1998. Longevity of subitaneous and diapause eggs of Centropages hamatus (Copepoda: Calanoida) from the northern Gulf of Mexico. Mar. Biol., 131: 249-257.

Marcus, N.H. - 1984a. Recruitment of copepod nauplii into the plankton: importance of diapause eggs and benthic processes. Mar. Ecol. Prog. Ser., 15: 47-54.

Marcus, N.H. - 1989. Abundance in bottom sediments and hatching requirements of eggs of Centropages hamatus (Copepoda: Calanoida) from the Alligator Harbor region, Florida. Biol. Bull., 176: 142-146.

Marcus, N.H. - 1990. Calanoid copepods, cladoceran, and rotifer eggs in sea-bottom sediments of northern Californian coastal waters: identification, occurrence and hatching. Mar. Biol., 105: 413-418.

Marcus, N.H. - 1995. Seasonal study of planktonic copepods and their benthic resting eggs in northern California coastal waters. Mar. Biol., 123: 459-465.

Marcus, N.H., R.V. Lutz, W. Burnett and P. Cable. - 1994. Age, viability and vertical distribution of zooplankton resting eggs from an anoxic basin: Evidence of an egg bank. Limnol. Oceanogr., 39: 154-158.

Masero, R. and F. Villate. - 2004. Composition, vertical distribution and age of zooplankton benthic eggs in the sediments of two contrasting estuaries of the Bay of Biscay. Hydrobiologia, 518: 203-214

Næss, T. - 1991. Marine calanoid resting eggs in Norway: abundance and distribution of two copepod species in the sediment of an enclosed marine basin. Mar. Biol., 110: 261-266.

Norrbin, M.F. - 1996. Timing of diapause in relation to the onset of winter in the high-latitude copepods Pseudocalanus acuspes and Acartia longiremis. Mar. Ecol. Prog. Ser., 142: 99-109.

Onbé, T. - 1978. Sugar flotation method for sorting the resting eggs of marine cladocerans and copepods from sea-bottom sediment. Bull. Japan Soc. Sci. Fish., 44: 1411.

San Vicente, C., A. Miner, J. D’Elbée and M. Ibáñez. - 1988. Estudio de las rías guipuzcoanas. 1. Primeros datos sobre el estudio de la ría de Orio. Lurralde, 11: 179-199.

Taylor, C.J.L. - 1987. The zooplankton of the Forth, Scotland. Proc. R. Soc. Edimb., B, 93: 377-388.

Uriarte, I. and F. Villate. - 2005. Differences in the abundance and distribution of copepods in two estuaries of the Basque coast (Bay of Biscay) in relation to pollution. J. Plankton Res., 27: 863-874.

Uriarte, I., U. Cotano and F. Villate. - 1998. Egg production of Acartia bifilosa in the small temperate estuary of Mundaka, Spain, in relation to environmental variables and population development. Mar. Ecol. Prog. Ser., 166: 197-205.

Uye, S.-I. - 1980. Development of neritic copepods Acartia clausi and A. steueri. I. Some environmental factors affecting egg development and the nature of resting eggs. Bull. Plankton Soc. Japan, 27: 1-9.

Uye, S.-I. - 1983. Seasonal cycles in abundance of resting eggs of Acartia steueri Smirnov (Copepoda: Calanoida) in sea-bottom mud of Onagawa Bay, Japan. Crustaceana, 44: 103-105.

Uye, S.-I. - 1985. Resting egg production as a life history strategy of marine planktonic copepods. Bull. Mar. Sci., 37: 440-449.

Valdés, L. and M. Moral. - 1998. Time-series analysis of copepod diversity and species richness in the southern Bay of Biscay off Santander, Spain, in relation to environmntal condictions. ICES J. Mar. Sci., 55: 783-792.

Viitasalo, M. and T. Katajisto. - 1994. Mesozooplankton resting eggs in the Baltic Sea: identification and vertical distribution in laminated and mixed sediments. Mar. Biol., 120: 455-465.

Viitasalo, M. - 1992a. Mesozooplankton of the Gulf of Finland and Northern Baltic Proper- a review of monitoring data. Ophelia, 35: 147-168.

Viitasalo, M. - 1992b. Calanoid resting eggs in the Baltic Sea: implications for the population dynamics of Acartia bifilosa (Copepoda). Mar. Biol., 114: 397-405.

Villate, F. and E. Orive. - 1981. Copépodos planctónicos del estuario de Plencia: composición distribución y abundancia. Munibe, 33: 87-100.

Villate, F. - 1991b. Zooplankton assemblages in the shallow tidal estuary of Mundaka (Bay of Biscay). Cah. Biol. Mar., 32: 105-119.

Villate, F. - 1997. Tidal influences on zonation and occurence of resident and temporary zooplankton in a shallow system (Estuary of Mundaka, Bay of Biscay). Sci. Mar., 61: 173-188.

Villate, F., A. Ruiz and J. Franco. - 1993. Summer zonation and development of zooplankton populations within a shallow mesotidal system: the estuary of Mundaka. Cah. Biol. Mar., 34 , 131-143.

Villate, F., M. Moral and V. Valencia. - 1997. Mesozooplakton community indicates climate changes in a shelf area of the inner Bay of Biscay throughout 1988 to 1990. J. Plankton Res., 19: 1617-1636.

Wik, M. and I. Renberg. - 1991. Recent atmospheric deposition in Sweden of carbonaceous particles from fossil-fuel combustion surveyed using lake sediments. Ambio, 20: 289-292.

Received February 24, 2006. Accepted June 8, 2006.

Scient. ed.: A. Ianora.

Published online October 23, 2006. 